\title{
FORMULASI DAN EVALUASI SEDIAAN OBAT KUMUR (MOUTHWASH) DARI EKSTRAK ETANOL DAUN KALANGKALA (Litsea angulata) SEBAGAI ANTISEPTIK MULUT
}

\section{Mouthwash Formulation and Evaluation of Kalangkala Leaves (Litsea angulata) Ethanol Extract as a Mouth Antiseptic}

\section{Rohama ${ }^{\text {* }}$ \\ Melviani $^{2}$}

*ISari Mulia University, Banjarmasin City, South Borneo 70238, Indonesia

*email: apt.rohama@gmail.com

Kata Kunci:

Daun Kalangkala

Sediaan Obat Kumur

Antiseptik Mulut

\section{Keywords:}

Kalangkala leaves

Mouthwash

Mouth Antiseptic

\begin{abstract}
Abstrak
Penelitian mengenai formulasi dan evaluasi sediaan obat kumur (mouthwash) ekstrak daun kalangkala (Litsea angulata) sebagai antiseptik mulut telah diuji pada bakteri Streptococcus mutans dengan variasi konsentrasi ekstrak 2\%, 2,5\%, dan 3\%, yang bertujuan untuk mengetahui formula sediaan paling ideal secara mutu fisik dan memiliki aktivitas antibakteri tertinggi berdasarkan zona hambat obat kumur (mouthwash) terhadap bakteri Streptococcus mutans. Metode yang digunakan meliputi tahap ekstraksi daun kalangkala, pembuatan sediaan obat kumur (mouthwash) dengan 3 formula FI (2\%), F2 (2,5\%), dan F3 (3\%) dilanjutkan dengan evaluasi formula yang meliputi uji organoleptis, uji $\mathrm{pH}$, uji viskositas dan uji daya hambat bakteri. Uji daya hambat bakteri menggunakan media NA dengan metode difusi agar. Pengujian stabilitas fisik dilakukan pada minggu ke-I, 2, 3, dan minggu ke-4. Berbagai variasi konsentrasi ekstrak daun kalangkala dalam sediaan obat kumur (mouthwash) memiliki pengaruh terhadap diameter zona hambat bakteri. Namun tidak memiliki pengaruh yang signifikan terhadap stabilitas fisik formula sediaan. Sediaan obat kumur (mouthwash) yang memiliki efektivitas daya hambat paling tinggi terhadap bakteri Streptococcus mutan adalah konsentrasi $3 \%$ yang terdapat pada F3.
\end{abstract} Palangkaraya. This is Open Access article under the CC-BY-SA License (http://creativecommons.org/licenses/by-sa/4.0/). DOI: https://doi.org//0.33084/jsm.vxix.xxx.

\section{PENDAHULUAN}

Mulut adalah salah satu bagian tubuh yang cukup vital karena diperlukan untuk aktivitas keseharian seperti berbicara, makan dan minum. Jika mulut terserang masalah maka kegiatan lain akan menjadi terganggu. Masalah mulut yang sering terjadi adalah bau mulut, sariawan, infeksi mulut, mulut kering, karies gigi dan radang gusi (Bustomi, 2010). Bakteri yang berperan penting dalam pembentukan plak gigi adalah bakteri yang mempunyai kemampuan untuk membentuk polisakarida ekstraselular, yaitu jenis Streptococcus mutans dan dapat membentuk koloni yang melekat erat pada permukaan gigi (Kidd, E.A.M and S.J, 1994). Streptococcus mutans adalah penghuni normal rongga mulut (Roeslan, 1996). Streptococcus mutans dapat 
berubah menjadi patogen bila lingkungan hidup bakteri tersebut menguntungkan dan terjadi peningkatan populasi Ini sejalan dengan hasil riset kesehatan dasar nasional yang dilakukan oleh Departemen Kesehatan pada tahun 2014 bahwa adanya peningkatan prevalensi terjadinya masalah kesehatan pada mulut, dan banyak diderita pada golongan usia 10-24 tahun atau kategori remaja (POM, 1999).

Pandemi COVID-19 yang merebak sejak awal tahun, masyarakat diajarkan untuk lebih menjaga kebersihan diri agar tidak terinfeksi salah satu bagian tubuh yang tidak boleh ketinggalan kebersihannya adalah mulut (Kurniawati dkk, 2020). Pasalnya, mulut jadi salah satu jalur virus corona bisa masuk ke tubuh. Obat kumur memang tidak dapat mencegah infeksi virus Corona secara langsung. Namun, menjaga kebersihan dan kesehatan gigi dan mulut dapat bermanfaat bagi sistem imun tubuh sehingga baik untuk dilakukan, apalagi di tengah pandemi COVID-19 seperti sekarang ini (Anastasia, 2020)

Pencegahan dapat dilakukan dengan bahan herbal, oleh karena itu penelitian tentang obat herbal harus terus dilakukan dengan harapan diperoleh pengobatan yang aman dan minim efek samping (Noval dkk, 2020) (Noval dkk, 202I). dan memiliki manfaat sebagai antimikroba yang dapat dimaksimalkan penggunaannya menjadi sebuah produk (Noval dkk, 2019). Salah satu contoh tanaman yang memiliki khasiat antimikroba yang berpotensi sebagai antiseptik mulut adalah tanaman Kalangkala (Litsea angulata). Secara tradisional masyarakat Kalimantan mengunakan tumbuhan Kalangkala (Litsea sp) untuk mengobati penyakit seperti diare, sakit perut, dyspepsia, gastroenteritis, diabetes, dll. Sebagian masyarakat Kalimantan Selatan menggunakan tanaman Kalangkala sebagai obat bisul. Karena bisul diakibatkan oleh bakteri, sehingga Kalangkala diduga memiliki aktivitas biologi sebagai antibakteri. Menurut penelitian sebelumnya tanaman Kalangkala mengandung senyawa metabolit sekunder flavonoid yang memiliki aktivitas antibakteri yang cukup tinggi. (Kusparini, dkk. 2018) Mouthwash merupakan larutan air yang digunakan sebagai pembersih untuk meningkatkan kesehatan rongga mulut, estetika dan keseragaman nafas (Gelone and Gennaro, 2005). Umumnya mouthwash mengandung bahan antibakteri dengan komponen utama berupa alkohol lebih dari 20\%, yang dapat memicu terjadinya kanker mulut (Mccullough and Farah, 2008).

Ekstrak Kalangkala sebagai bahan alam dapat dimanfaatkan agar dapat mengurangi penggunaan bahan sintetik dalam pengobatan. Potensi Kalangkala dalam menghambat maupun membunuh bakteri serta belum adanya pemanfaatan ekstrak Kalangkala sebagai bahan aktif pada sediaan mouthwash yang digunakan untuk mencegah bau mulut, menghambat maupun membunuh mikroba penyebab bau mulut serta efektif dalam menjangkau bagian gigi yang tidak dapat dibersihkan dengan menyikat gigi melatarbelakangi penelitian tentang formulasi sediaan mouthwash dari ekstrak Kalangkala ini.

Berdasarkan latar belakang di atas, peneliti tertarik ingin melakukan penelitian dengan tujuan untuk memformulasikan ekstrak daun kalangkala menjadi sediaan obat kumur (mouthwash) dan melakukan evaluasi untuk mendapatkan sediaan yang stabil, serta pengujian pada bakteri Streptococcus mutans yang bermanfaat untuk antiseptik mulut.

\section{METODOLOGI}

\section{Alat dan Bahan}

Alat yang digunakan yaitu rotary evaporator, timbangan analitik, gelas beker, gelas ukur, bejana, pipet tetes, batang pengaduk, pisau, gunting, botol maserasi, erlenmeyer, corong, $\mathrm{pH}$ meter, viscometer stormer, autoklaf, cawan petri, hot plate, inkubator, magnetic stirrer, mikro pipet, mortir, stamper, dan botol kemasan. 
Bahan yang digunakan yaitu Daun Kalangkala (Litsea angulata), etanol 96\%, aquadest, bakteri Streptococcus mutans, media $\mathrm{NA}, \mathrm{H} 2 \mathrm{SO} 4, \mathrm{BaCl}$, sorbitol, gliserin, natrium benzoat, menthol, $\mathrm{NaCl} 0,9 \%$, paper disk.

\section{Metode Penelitian}

Persiapan Alat dan Bahan

Sampel Daun Kalangkala (Litsea angulata) didapat dari daerah Kotabaru, Kalimantan Selatan.

Pembuatan Ekstrak Etanol Daun Kalangkala

Tahapan ekstraksi adalah sebagai berikut:

I. Simplisia dari Daun Kalangkala (Litsea angulata) dimasukkan ke dalam bejana maserasi.

2. Dimasukkan etanol ke dalam bejana sampai merendam simplisia setinggi $2-3 \mathrm{~cm}$

3. Bejana maserasi ditutup dan biarkan rendaman selama 3 hari sambil sesekali di aduk

4. Cairan hasil ekstraksi dikeluarkan dari bejana dengan disaring

5. Filtrat kemudian diuapkan menggunakan rotary evaporator sampai didapatkan ekstrak kental.

Formulasi Sediaan Obat Kumur (Mouthwash) Ekstrak Etanol Daun Kalangkala

Tabel I.Variasi Formulasi Obat Kumur

\begin{tabular}{|l|c|c|c|c|}
\hline \multirow{2}{*}{ Bahan } & \multicolumn{4}{c|}{ Konsentrasi (\%) } \\
\cline { 2 - 5 } & $\begin{array}{c}\text { Kontrol } \\
(-)\end{array}$ & $\mathrm{Fl}$ & $\mathrm{F} 2$ & $\mathrm{~F} 3$ \\
\hline $\begin{array}{l}\text { Ekstrak Daun } \\
\text { Kalangkala }\end{array}$ & - & 2 & 2,5 & 3 \\
\hline Gliserin & 4 & 4 & 4 & 4 \\
\hline Sorbitol & 9 & 9 & 9 & 9 \\
\hline Natrium Benzoat & 0,5 & 0,5 & 0,5 & 0,5 \\
\hline Peppermint Oil & 0,15 & 0,15 & 0,15 & 0,15 \\
\hline Aquadest ad & $100 \mathrm{ml}$ & $100 \mathrm{ml}$ & $100 \mathrm{ml}$ & $100 \mathrm{ml}$ \\
\hline
\end{tabular}

Ekstrak dimasukkan kedalam mortir ditambahkan gliserin dan digerus hingga homogen, dimasukkan sorbitol dan $\mathrm{Na}$ benzoat lalu digerus hingga homogen, aquadest add $100 \mathrm{ml}$, dilakukan penyaringan dan dimasukan kedalam botol, diberikan peppermint oil 3-4 tetes (Handayani, Warnida and Nur, 2016).

Evaluasi Mouthwash Ekstrak Etanol Daun Kalangkala
I. Uji organoleptis

Pemeriksaan organoleptik meliputi, bentuk, warna, bau dan rasa (Noval dkk, 202l).

2. Uji derajat keasaman $(\mathrm{pH})$

Pengujian $\mathrm{pH}$ menggunakan $\mathrm{pH}$ meter (Haryono dkk, 202l).

3. Uji viskositas

Pengujian viskositas menggunakan Viskometer Stormer, rotor No. 2 dengan kecepatan 30 dan 60 rpm (Harliantika dkk, 202I).

Pengujian mouthwash pada bakteri Streptococcus mutans

I. Sterilisasi

Alat-alat dibungkus dengan kertas minyak kemudian disterilisasi menggunakan autoklaf suhu $121^{\circ} \mathrm{C}$ selama 15 menit.

2. Pembuatan media

Media yang digunakan adalah NA sebanyak 2 gram dilarutkan dalam $100 \mathrm{ml}$ aquadest, kemudian dipanaskan dan disterilisasi sampai siap menjadi media

(Retnowati, 20II).

3. Pembuatan standar kekeruhan larutan

Pembuatan standar kekeruhan menggunakan Larutan Mc. Farland (Whitman and Macnair, 20I0; Sutton, 20II).

4. Pembuatan suspense bakteri uji

Bakteri disuspensikan kedalam tabung yang berisi $2 \mathrm{ml}$ larutan $\mathrm{NaCl}$ 0,19\% hingga diperoleh kekeruhan yang sama denganstandar kekeruhan larutan Mc. Farland (Handayani, Warnida and Nur, 2016).

5. Perendaman paper disk pada mouthwash Paper disk yang telah disiapkan direndam dalam semua formula dan kontrol negatif, dalam waktu I5-30 menit.

6. Uji aktivitas antibakteri dengan metode difusi agar

Siapkan 5 cawan petri, dituang media NA $15 \mathrm{ml}$ kemasing-masing cawan hingga homogen dan biarkan memadat. Dicelupkan lidi kapas steril kedalam bakteri 
hingga meresap. Kemudian kapas diangkat dan diusapkan kesemua bagian permukaan media, tunggu hingga 15 menit supaya meresap. Selanjutnya paper disk yang telah direndam dalam formula ekstrak mouthwash dan control negative ditempelkan. Setelah itu, dilakukan inkubasi selama 24 jam pada suhu $37^{\circ} \mathrm{C}$. kemudian diukur diameter zona hambat $(\mathrm{mm})$ (Anastasia, Yuliet and Tandah, 2017).

\section{HASIL DAN PEMBAHASAN}

Obat kumur (mouthwash) merupakan salah satu sediaan mulut yang banyak beredar di pasaran. Salah satu keuntungan mouthwash yaitu mudah dibawa kemana-mana. Selain itu, mouthwash praktis ketika digunakan dibandingkan dengan sediaan mulut lainnya (Akarina, 20I I).

Pandemi Covid-19 yang merebak sejak awal tahun 2020, mouthwash merupakan salah satu barang yang wajib ada selain masker dan handsanitizer bahkan keberadaanya sempat menjadi langka dan harga yang melambung tinggi.

Evaluasi fisik sediaan obat kumur (mouthwash) ekstrak Daun Kalangkala (Litsea angulata) dilakukan uji organoleptis, uji $\mathrm{pH}$ dan uji viskositas. Adapun hasil evaluasi uji organoleptis dapat dilihat pada tabel di bawah ini:

\section{Uji organoleptis}

Tabel II. Hasil Uji Organoleptis Obat Kumur Ekstrak Daun Kalangkala (Litsea angulata)

\begin{tabular}{ccccc}
\hline Organoleptis & Minggu & \multicolumn{3}{c}{ Formula } \\
\cline { 3 - 5 } Ke- & FI & F2 & F3 \\
\cline { 3 - 5 } & & Hijau muda & Hijau muda & Hijau muda \\
& & keruh & keruh & keruh \\
\cline { 2 - 5 } & 2 & Hijau muda & Hijau muda & Hijau muda \\
& & keruh & keruh & keruh \\
& 3 & Hijau muda & Hijau muda & Hijau muda \\
& & keruh & keruh & keruh \\
\cline { 2 - 5 } & 4 & Hijau muda & Hijau muda & Hijau muda \\
& & keruh & keruh & keruh \\
\hline Bau & I & Menthol & Menthol & Menthol
\end{tabular}

\begin{tabular}{|c|c|c|c|c|}
\hline & 2 & Menthol & Menthol & Menthol \\
\hline & 3 & Menthol & Menthol & Menthol \\
\hline & 4 & Menthol & Menthol & Menthol \\
\hline \multirow[t]{4}{*}{ Rasa } & I & Mint & Mint & Mint \\
\hline & 2 & Mint & Mint & Mint \\
\hline & 3 & Mint & Mint & Mint \\
\hline & 4 & Mint & Mint & Mint \\
\hline \multirow[t]{4}{*}{ Bentuk } & I & Cair & Cair & Cair \\
\hline & 2 & Cair & Cair & Cair \\
\hline & 3 & Cair & Cair & Cair \\
\hline & 4 & Cair & Cair & Cair \\
\hline
\end{tabular}

Berdasarkan pengujian yang dilakukan, didapatkan data sebagaimana dalam tabel II. Pengujian organoleptis dilakukan pada minggu ke-I,2,3, sampai minggu ke-4 penyimpanan. Data evaluasi menunjukkan bahwa sediaan tidak mengalami perubahan yang signifikan dari pengujian yang pertama sampai minggu ke 4 yang meliputi warna, bau, rasa dan bentuk (Mardiana, Gadri and Mulqie, 20I5).

Hasil evaluasi warna, warna awal sediaan sebelum penyimpanan Hijau muda keruh pada semua formula FI, F2, dan F3. Kemudian pada minggu ke 2, ke 3, dan ke 4 sediaan tetap berwarna hijau muda keruh pada semua formula.

Hasil evaluasi evaluasi bau sediaan adalah bau seperti menthol diminggu pertama, ke 2, ke 3 dan ke 4 .

Hasil evaluasi bentuk yaitu, bentuk sediaan yang dihasilkan adalah cair selama 4 minggu penyimpanan. Adapun hasil evaluasi rasa sediaan yaitu, seperti rasa mint dan tidak ada perubahan selama 4 minggu penyimpanan. Rasa mint dan bau menthol pada sediaan dipengaruhi oleh penggunaan peppermint oil dan gliserin (Handayani, Warnida and Nur, 2016). 


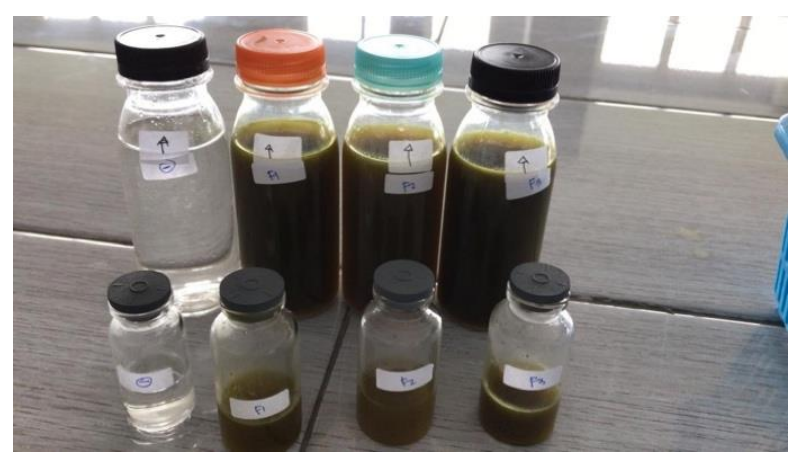

Gambar I. Sediaan Obat Kumur (mouthwash) Ekstrak Daun Kalangkala (Litsea angulata)

2. $U \mathrm{ji} \mathrm{pH}$

Tabel III. Hasil Uji pH Obat Kumur Ekstrak Etanol Daun Kalangkala (Litsea angulata)

\begin{tabular}{ccccc} 
Formula & \multicolumn{5}{c}{$\mathbf{p H}$} \\
& & & \\
& Mg ke-I & Mg ke- 2 & Mg ke- 3 & Mg ke- 4 \\
\hline I & 6,85 & 5,8 I & 5,82 & 5,99 \\
\hline II & 6,55 & 5,8 I & 5,86 & 5,96 \\
\hline III & 6,44 & 5,68 & 5,72 & 5,26 \\
\hline
\end{tabular}

Pengujian $\mathrm{pH}$ pada sediaan obat kumur bertujuan untuk mengetahui nilai $\mathrm{pH}$ obat kumur yang dihasilkan (Lucida, Bakhtiar and Putri, 2007). Pada pengujian pH terjadi perubahan yang berbeda untuk setiap formula, dapat dilihat dalam tabel III bahwa FI mengalami penurunan nilai $\mathrm{pH}$ di minggu ke 2 menjadi 5,8I, minggu ke 3 naik sedikit menjadi 5,82, minggu ke 4 naik menjadi 5,99. Adapun hasil uji $\mathrm{pH}$ pada $\mathrm{F} 2$ mengalami penurunan nilai $\mathrm{pH}$ dari 6,55 menjadi 5,8I, menurun menjadi 5,86 diminggu ke 3 sedangkan pada minggu ke 4 nilai $\mathrm{pH}$ naik menjadi 5,96.

Hasil uji pH F3 mengalami penurunan nilai $\mathrm{pH}$ yang dari 6,44 menjadi 5,68 di minggu ke 2. Lalu menjadi 5,72 di minggu ke 3 dan turun menjadi 5,26 pada minggu ke 4. Secara umum, nilai $\mathrm{pH}$ yang diperuntukan bagi sediaan yang ditujukan untuk kesehatan mulut berkisar antara 4,5 hingga 10 dan lebih baik berkisar antara 6,5-8 (Lucida, Bakhtiar and Putri, 2007). Selain itu, nilai $\mathrm{pH}$ suatu sediaan menentukan jenis dan kemampuan bakteri untuk tumbuh. Kebanyakan $\mathrm{pH}$ optimum pertumbuhan bakteri, yaitu sekitar $\mathrm{pH}$ 6,57,5, sehingga nilai $\mathrm{pH}$ sediaan obat kumur (mouthwash) diharapkan dapat berada di luar range pertumbuhan bakteri (Pradewa, 2008). Nilai pH yang dihasilkan pada FI, F2, dan F3 memenuhi persyaratan karena berada di luar range $\mathrm{pH}$ pertumbuhan bakteri dan dalam rentang $\mathrm{pH}$ sediaan yang ditujukan untuk kesehatan mulut (Pradewa, 2008). Namun, nilai pH yang diperoleh diminggu ke 2 sampai ke 4 cukup asam dipengaruhi oleh penggunaan sorbitol dengan tingkat keasaman sebesar 4,5 (Rowe, Sheskey and Owen, 2009). Pada formulasi sediaan, sorbitol yang digunakan memiliki nilai konsentrasi terbesar dibandingkan bahan-bahan lainnya sebesar $9 \%$ sehingga mempengaruhi nilai $\mathrm{pH}$ pada sediaan (Rowe, Sheskey and Owen, 2009). Seperti pada penelitian (Ardana, Aeyni and Ibrahim, 2015) juga menyebutkan setelah penyimpanan terjadi naik turunnya nilai $\mathrm{pH}$ pada sediaan, tetapi perubahan $\mathrm{pH}$ tidak terjadi secara signifikan. Maka sediaan ini dapat dikatakan stabil selama penyimpanan. Formula yang paling ideal dalam uji sifat fisik ini adalah F3 dengan nilai $\mathrm{pH}$ setelah penyimpanan berikisar antara 5-6.

\section{Uji Viskositas}

Tabel IV. Hasil Uji Viskositas Obat Kumur (mouthwash) Ekstrak Etanol Daun Kalangkala (Litsea angulata)

\begin{tabular}{cccccc}
\hline Formula & Rpm & \multicolumn{4}{c}{ Viskositas (mPa.S) } \\
\cline { 3 - 6 } & & $\begin{array}{c}\text { Minggu } \\
\text { ke I }\end{array}$ & $\begin{array}{c}\text { Minggu } \\
\text { ke 2 }\end{array}$ & $\begin{array}{c}\text { Minggu } \\
\text { ke 3 }\end{array}$ & $\begin{array}{c}\text { Minggu } \\
\text { ke 4 }\end{array}$ \\
\hline FI & 30 & 37 & 37 & 40 & 43 \\
& 60 & 19 & 15,5 & 19,5 & 13,99 \\
\hline F2 & 30 & 27 & 39 & 32 & 55 \\
\hline F3 & 60 & 18 & 18 & 20 & 6,99 \\
& 30 & 27 & 40 & 51.9 & 46 \\
\hline & 60 & 12,99 & 22,5 & 8,5 & 23 \\
\hline
\end{tabular}

Pengujian viskositas bertujuan untuk menentukan nilai kekentalan suatu zat (Noval, Rosyifa and Annisa, 2020). Viskositas suatu formulasi sangat mempengaruhi 
tingkat kekentalan sediaan obat kumur saat digunakan berkumur di dalam mulut, semakin dekat tingkat viskositas suatu produk formulasi dengan tingkat viskositas air, maka semakin mudah dan nyaman produk tersebut digunakan untuk berkumur. Tingkat viskositas air murni adalah I $\mathrm{mPa}$.s atau sekitar $\pm \mathrm{I} \mathrm{cP}$, sedangkan viskositas standar mouthwash yang beredar di pasaran adalah $\pm 7,25$ (Rowe, Sheskey and Owen, 2009).

Pengujian viskositas menggunakan Viskometer Stormer dengan rotor nomor 2. Berdasarkan data tabel hasil pengukuran viskositas obat kumur (mouthwash) ekstrak daun kalangkala (Litsea angulata) menunjukkan bahwa, hasil uji viskositas minggu pertama pada FI, F2 dan F3 dengan kecepatan $30 \mathrm{rpm}$ dan $60 \mathrm{rpm}$ diperoleh hasil yang sama baiknya.

Hasil uji viskositas diminggu kedua, minggu ketiga, dan minggu keempat pada FI, F2, dan F3 dengan kecepatan $30 \mathrm{rpm}$ dan $60 \mathrm{rpm}$ berturut-turut diperoleh hasil sifat alir yang sama baiknya juga karena semakin tinggi kecepatan viskometer (rpm), nilai viskositas yang didapat semakin turun, artinya sediaan semakin baik yaitu memiliki aliran pseudoplastis (Lachman and Lieberman, 1994). Pada aliran pseudoplastis viskositas akan berkurang atau menurun dengan meningkatnya rate of share (Martin, et al, 1993)

Adapun nilai viskositas diminggu pertama pada FI, F2, dan F3 berkisar antara 37-12,99, diminggu kedua berkisar antara 40-15,5, minggu ketiga berkisar antara 51,9-8,5, dan minggu keempat bekisar antara 55-13,99. Terlihat bahwa untuk nilai pada setiap minggunya terjadi perubahan nilai viskositas yang artinya viskositas sediaan selama penyimpanan mengalami ketidakstabilan dan obat kumur (mouthwash) ekstrak etanol tanaman kalangkala memiliki viskositas yang lebih besar daripada viskositas air (Rowe, Sheskey and Owen, 2009).

Faktor penyebab ketidakstabilan viskositas disebabkan karena penggunaan bahan aktif ekstrak tanaman kalangkala dimana partikel-partikel halusnya tidak homogen. Penggunaan sorbitol yang konsentrasinya $9 \%$ atau lebih tinggi dari bahan lain juga bisa mempengaruhi kekentalan sediaan. Sorbitol sudah memiliki nilai viskositas sebesar I,2 cP pada konsentrasi 10\% (Rowe, Sheskey and Owen, 2009). Selain itu, hal ini juga disebabkan karena sediaan berupa larutan masa simpannya relatif lebih singkat dibandingkan dengan bentuk sediaan padat, karena sediaan larutan mudah terurai oleh suhu dan cahaya dan bereaksi dengan lingkungan (Handayani, Warnida and Nur, 2016). Menurut (Nugraha, 20I2) sifat aliran dari suatu sediaan akan mempengaruhi stabilitas fisik dan ketersediaan hayati. Sedangkan menurut (Martin, 2008) sifat aliran dapat menurun disebabkan besar dan bentuk molekul, suhu, serta adanya koloid dapat meningkatkan sifat aliran dan adanya elektrolit dapat menurunkan sifat aliran.

4. Uji Daya Hambat Bakteri Streptococcus mutan

Tabel V. Hasil Uji Daya Hambat Bakteri Streptococcus mutans Obat Kumur (mouthwash) Ekstrak Etanol Daun Kalangkala (Litsea angulata)

\begin{tabular}{ccc}
\hline \multicolumn{4}{c}{ Diameter Zona Hambat (mm) } \\
Formulasi \\
\hline I & II & III \\
\hline 9 & 12 & 14
\end{tabular}

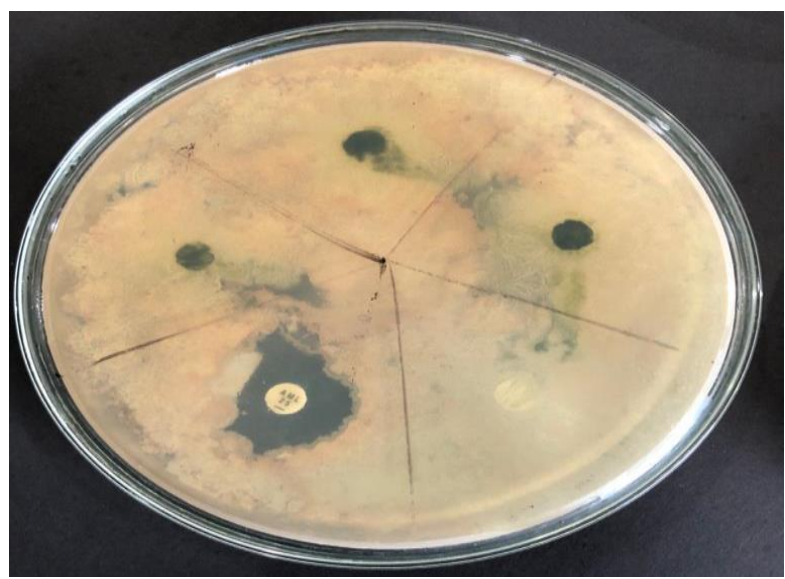




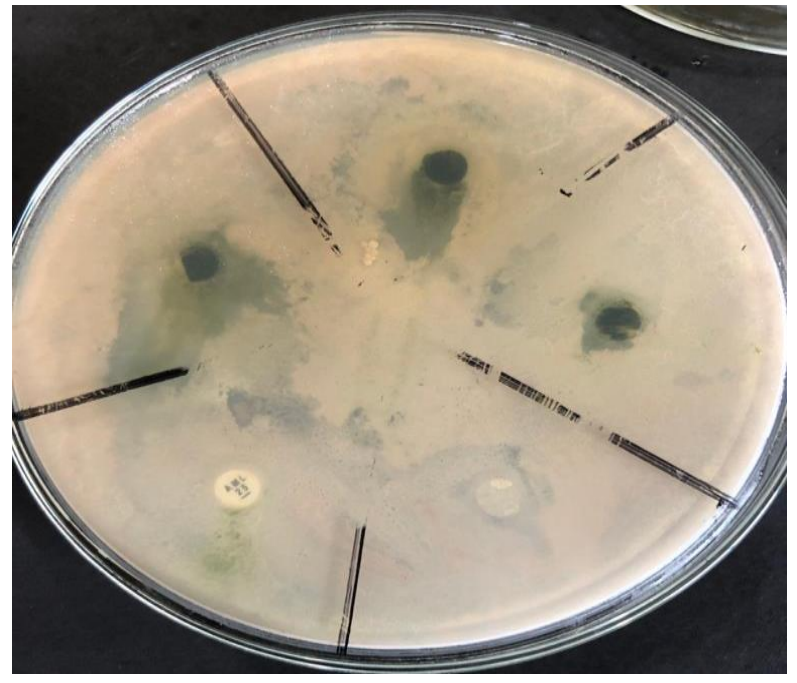

Gambar II. Zona Hambat Obat Kumur (mouthwash)

Ekstrak Daun Kalangkala (Litsea angulata) Terhadap

Bakteri Streptococcus mutans.

Uji aktivitas antibakteri menggunakan metode difusi agar dengan $2 x$ replikasi dengan rata-rata nilai daya hambat dapat dilihat pada tabel V. Metode difusi agar umumnya sering digunakan dibandingkan metode lainnya karena metode difusi agar memudahkan dalam mengetahui aktivitas antimikroba suatu sediaan dengan terbentuknya zona hambatan pertumbuhan bakteri di dalam media padat. Zona hambatan pertumbuhan bakteri adalah daerah jernih disekitar cakram. semakin kuat daya aktivitas antibakterinya maka semakin luas daerah hambatnya (Jawetz, 1996).

Menurut penelitian sebelumnya, ekstrak tanaman kalangkala memiliki daya hambat pada semua konsentrasi. Berdasarkan penelitian tersebut formulasi sediaan obat kumur (mouthwash) dibuat dengan memvariasikan konsentrasi ekstrak sebesar $2 \%$ pada FI, 2,5\% pada F2, dan 3 \% pada F3.

Hasil pengukuran zona hambat yang diperoleh yaitu diameter zona bening tiap formula mengalami peningkatan. Pada FI konsentrasi 2\% diameter zona bening yang diperoleh sebesar $9 \mathrm{~mm}$, F2 konsentrasi 2,5\% sebesar $12 \mathrm{~mm}$, dan F3 konsentrasi 3\% sebesar $14 \mathrm{~mm}$. Hal ini disebabakan karena semakin besar konsentrasi ekstrak yang terkandung dalam sediaan, semakin besar pula senyawa aktif yang dimilikinya (Noval dkk, 2020). Daya hambat dibagi atas, sangat kuat (zona jernih > $20 \mathrm{~mm}$ ), kuat (zona jernih 10-20 $\mathrm{mm}$ ), sedang (zona jernih $5-10 \mathrm{~mm}$ ) dan lemah (zona jernih $<5 \mathrm{~mm}$ )(Davis and Stout, 1971), sehingga dapat dinyatakan bahwa FI memiliki daya hambat sedang, sedangkan F2 dan F3 memiliki daya hambat kuat terhadap bakteri Streptococcus mutans. Adapun sediaan yang memiliki efektivitas tertinggi adalah F3, konsentrasi $3 \%$ dengan diameter zona hambat $14 \mathrm{~mm}$.

\section{KESIMPULAN}

Berdasarkan penelitian yang telah dilakukan sediaan obat kumur (mouthwash) Ekstrak Daun Kalangkala (Litsea angulata) Terhadap Bakteri Streptococcus mutans didapatkan F3 dengan konsentrasi 3\% memiliki efektivitas daya hambat paling kuat terhadap bakteri Streptococcus mutans diantara formula lainnya. Hasil evaluasi sifat fisik sediaan stabil, kecuali pada uji viskositas terdapat ketidakstabilan pada beberapa formula.

\section{UCAPAN TERIMA KASIH}

Peneliti mengucapkan terimakasih dan apresiasi sebesar-besarnya kepada Kementerian Riset dan Teknologi/ Badan Riset dan Inovasi Nasional Republik Indonesia yang mendanai penelitian ini melalui skema hibah "Penelitian Dosen Pemula" di tahun 202I.

\section{REFERENSI}

I. Bustomi, E. (2010) Mouthwas Life Style atau Kesehatan? Agustus 13, 2019, http://www.pitoyo.com

2. Kidd, E.A.M and S.J, B. (1994) Dasar-Dasar Karies Penyakit dan Penanggulangannya. Terjemahan. Jakarta: EGC.

3. Roeslan, B. O. (1996) Karakteristik Streptococcus mutans Penyebab Karies gigi. Majalah II. FKG Usakti.

4. POM, D. (1999) Farmakope Indonesia. IV. Jakarta: 
Depkes RI.

5. Kurniawati, Darini, Noval Noval, and Kunti Nastiti. 2020. "POTENSI ANTISEPTIK POLIHERBAL DAUN SIRIH (Piper Betle), KULIT JERUK NIPIS (Citrus Aurantifolia) DAN TANAMAN BUNDUNG (Actinuscirpus Grossus) PADA TINDAKAN KEPERAWATAN DAN KEBIDANAN." Dinamika Kesehatan: Jurnal Kebidanan Dan Keperawatan I I(I): 420-3I.

6. Anastasia, A., Yuliet and Tandah, M. R. (20/7) 'Formulasi Sediaan Mouthwash Pencegah Plak Gigi Ekstrak Biji Kakao ( Theobroma Cacao L ) Dan Uji Efektivitas Pada Bakteri Streptococcus Mutans', GALENIKA Journal of Pharmacy, 3(March), Pp. 84-92.

7. Noval, N., Nastiti, K., Nugraha, D., Rahmadani, R., \& Alawiyah, T. (2020). PRODUK INOVASI HAND SANITIZER DARI AKAR BAJAKAH SEBAGAI UPAYA PENCEGAHAN DI MASA PANDEMI COVID-19. LOGISTA - Jurnal Ilmiah Pengabdian Kepada Masyarakat, 4(2), 305-312. doi: 10.25077/logista.4.2.305-3 | 2.2020.

8. Noval, N., Appriliani, R., \& Oktaviannoor, H. (202I). Evaluasi Pengaruh Konsentrasi Pati Biji Cempedak (Artocarpus champeden) sebagai Bahan Pengisi pada Formulasi Tablet Paracetamol. Jurnal Surya Medika (JSM), 6(2), IIII I8. https://doi.org/10.33084/jsm.v6i2.2127.

9. Noval, N., Yuwindry, I., \& Syahrina, D. (2019). Phytochemical Screening and Antimicrobial Activity of Bundung Plants Extract by Dilution Method. Jurnal Surya Medika. https://doi.org/10.33084/jsm.v5il.954.

10. Kuspradini, H. Putri, AS, Diana, R. 2018. Potensi Tumbuhan Genus Litsea. Samarinda: Mulawarman University Press

II. Gelone, S. and Gennaro, A. (2005) 'Remingtons The Sciences and Practice of Pharmacy ed 2 Ith', Lippincot Williams \& Wilkins Philadelpia 1672.

12. Mccullough, M. J. and Farah, C. S. (2008) 'The role of alcohol in oral carcinogenesis with particular reference to alcohol-containing mouthwashes', Australian Dental Journal, PP. 302-305. doi: |0.1 | | |/j.|834-78|9.2008.00070.x.
13. Handayani, F., Warnida, H. and Nur, S. J. (20l6) 'Formulasi Dan Uji Aktivitas Antibakteri Streptococcus Mutans Dari Sediaan Mouthwash Ekstrak Daun Salam (Syzygium polyanthum (Wight) Walp.)', Media Sains, 9(April), pp. 74-84.

14. Noval, N., Nugraha, D. F., Nastiti, K., Syahrina, D., \& Novia, N. (202I). Local Natural Product Development in the Era of Covid 19 Pandemic. Indonesia Berdaya, 2(2), I33-140.

I5. Haryono, I. A., Noval, N., \& Nugraha, B. (202I). Formulasi Buah Tampoi (Baccaurea macrocarpa) dalam Sediaan Masker Gel sebagai Antiaging. Jurnal Surya Medika (JSM), 6(2), I02-II0. https://doi.org//0.33084/jsm.v6i2.2126

16. Harliantika, Y. (202I). Formulasi dan Evaluasi Hidrogel Ekstrak Etanol Daun Gaharu (Aquilaria malacensis Lamk.) dengan Kombinasi Basis Karbopol 940 dan HPMC K4M. Journal of Pharmacy and Science, 6(I), 37-46.

17. Retnowati, Yuliana., Bialangi, Nurhayati., Posangi, Nona Wingti. 20II. Pertumbuhan Bakteri Staphylococcus aureus pada Media yang Diekspos dengan Infus Daun Sambiloto (Andrographis paniculata). Saintek Vol.6 No.2.

18. Whitman, H. and Macnair, N. G. (2010) 'Finfish and Shelfish Bacteriology Manual', in Techniques and Procedures.

19. Sutton, S. (201I) 'Determination of Inoculum for Microbilogical Testing', Journal of GXP Compliance.

20. Anastasia, Tamara. 2020. Kandungan Povidonelodine Dalam Obat Kumur Bisa Cegah Virus Corona, Maksudnya? Oktober 21, 2020. https://www.klikdokter.com/

2I. Akarina, W. (20II) 'Pengaruh Konsentrasi Humektan terhadap Stabilitas Formula Obat Kumur', Jurnal USU Medan.

22. Mardiana, Z. H., Gadri, A. and Mulqie, L. (2015) 'Formulasi Gel yang Mengandung Lendir Bekicot (Achatina Fulica) serta Uji Aktivitas Antibakteri terhadap Propionibacterium Acnes [PROSIDING]', Prosiding Penelitian SPeSIA, (2007), Pp. 223-230. 
23. Lucida, H., Bakhtiar, A. and Putri, A. (2007) 'Formulasi Sediaan Antiseptik Mulut dari Katekin Gambir', J. Sains Tek. Far., I2(I).

24. Pradewa, M. R. (2008) 'Formulasi Sediaan Obat Kumur (Mouthwash) Berbahan Dasar Gambir', Bogor ITB.

25. Rowe, R. C., Sheskey, P. J. and Owen, S. C. (2009) Handbook of Pharmaceutical Exipiens. 6th edn. London: American Pharmaceutical Association.

26. Ardana, M., Aeyni, V. and Ibrahim, A. (20I5) 'Formulasi dan optimasi basis gel hpmc (', J. Trop. Pharm. Chem, 3(2), pp. I0I-108.

27. Noval, Rosyifa and Annisa (2020) 'Effect of HPMC Concentration Variation as Gelling Agent on Physical Stability of Formulation Gel Ethanol Extract Bundung Plants (Actinuscirpus Grossus )'. doi: I0.4 I08/eai.23-II-2019.2298326.

28. Lachman, L. and Lieberman, H. A. (1994) Teori dan Praktek Farmasi Industri. Kedua. Jakarta: UI Press.

29. Martin; et al (1993) Farmasi Fisik. Ketiga. Jakarta: UI Press.

30. Nugraha, L. S. A. (20I2) Pengaruh Kadar Na CMC Sebagai Bahan Pengental Terhadap Karakteristik Fisik Losion Repelan Minyak Akar Wangi (Vetiveria zizanioides (L.) Nash).

31. Jawetz (1996) Mikrobiologi Kedokteran. 23rd edn. Jakarta: Buku Kedokteran EKG.

32. Noval, Noval, Melviani Melviani, Novia Novia, and Dahlia Syahrina. 2020. "Formulasi Dan Evaluasi Sediaan Obat Kumur (Mouthwash) Dari Ekstrak Etanol Tanaman Bundung (Actinoscirpus Grossus) Sebagai Antiseptik Mulut". Jurnal Surya Medika (JSM) $6 \quad$ (I), II2-20. https://doi.org/l0.33084/jsm.v6il.1626.

33. Martin, A. (2008) Farmasi Fisik Dasar-Dasar Kimia Fisik dalam IImu Farmasetik. Jakarta: Universitas Indonesia. 